\title{
Artikel
}

\section{Een kinderrechtenproof Vlaams jeugddelinquentierecht?}

\author{
K. (Katrien) Herbots en S. (Sofie) van Rumst*
}

Enkel langs het pad van de nacht kan men de morgenschemering bereiken.

\section{K. Gibran ${ }^{1}$}

\section{Inleiding}

De bevoegdheid tot wet- en regelgeving op het vlak van jeugd komt in de Belgische federale Staat toe aan de Gemeenschappen. Als gevolg hiervan bestaan er aanzienlijke verschillen in benadering en visie tussen de Vlaamse Gemeenschap en de Franse Gemeenschap, met daar bovenop een specifieke regeling in Brussel. België kent dus drie verschillende juridische stelsels op dit vlak.

In dit artikel ligt de focus op de situatie in Vlaanderen.

Met de aanname van het Jeugddelinquentiedecreet, bepaalt Vlaanderen de richting die het wil uitgaan in het omgaan met personen die op minderjarige leeftijd strafbare feiten plegen of hiervan verdacht worden. Zo ambieerde Vlaanderen onder meer zich internationaal als goede praktijk in de aanpak van jeugddelinquentie te profileren'. ${ }^{2}$

Katrien Herbots is Raadgever Jeugd en Kinderrechten bij Vlaams minister van Brussel, Jeugd en Media. Sofie van Rumst is advocaat en beleidsadviseur Kinderrechtencommissariaat. Deze bijdrage is een bewerking van een eerder gepubliceerde versie van deze bijdrage in J. Leenknegt \& J. Put, Het Vlaams jeugddelinquentierecht, Brussel/ Gent: Larcier 2019.

1. K. Gibran, Spiegels van de ziel. De mooiste verhalen van Kahlil Gibran, Utrecht: Servire 1994

2. Beleidsnota 2014-2019 Welzijn, Volksgezondheid en Gezin, ingediend door de heer Jo Vandeurzen, Vlaams Minister van Welzijn, Volksge-
Om internationaal een toonbeeld te kunnen zijn, zal minstens het internationaal kinderrechtenkader een belangrijke toetssteen vormen. Op het gebied van de omschrijving, preventie en aanpak van jeugddelinquentie tekenen momenteel zowel specifieke kinderrechteninstrumenten, als algemene mensenrechteninstrumenten belangrijke grondbeginselen, normen en krijtlijnen uit. $^{3}$

Deze bijdrage gaat vanuit een kinderrechtenperspectief na in welke mate het nieuwe decreet deze internationale ambitie waar maakt. zondheid en Gezin, www.vlaanderen.be/nl/publicaties/detail/ beleidsnota-2014-2019-welzijn-volksgezondheid-en-gezin.

3. K. Herbots, H. Asselman \& J. Put, Rapport 4. Het Kinderrechterrechtelijk kader, Leuven-Gent, KeKi - ISR, KU Leuven, 2015, www.keki.be/ sites/default/files/publications/Omgevingsanalyse \%20-\%20Rapport \%204\%20-\%20Kinderrechtelijk\%20kader\%20-\%20KeKi.pdf, 58 pagina's. Dit rapport is een onderdeel van het onderzoeksproject 'Omgevingsanalyse Vlaams jeugdrecht', uitgevoerd door KU Leuven, UGent, Vrije Universiteit Brussel en Kenniscentrum Kinderrechten, in opdracht van het Agentschap Jongerenwelzijn. Hierna: Rapport Kinderrechtelijk kader Omgevingsanalyse Jeugdrecht 2015. 


\section{De betekenis en het belang van het internationaal kinderrechtenkader op het vlak van jeugddelinquentie 4}

Kinderrechten zijn een essentiële bouwsteen in het nieuw jeugddelinquentierecht. ${ }^{5}$ Kinderrechten weerspiegelen de rol en de plaats die kinderen en jongeren worden toegekend in een samenleving. ${ }^{6}$

Kinderrechten gelden voor alle kinderen en jongeren, dus ook voor hen die over de schreef gaan, die een delict plegen of maatschappelijke normen overschrijden. ${ }^{7}$

Op internationaal niveau ${ }^{8}$ is voor de anpak en het omgaan met jeugddelinquentie uitdrukkelijk de optie naar voren geschoven van een kmaliteitsvol en comprehensief jeugddelinquentierechtssysteem, afzonderlijk van het gemeen strafrecht. De uitwerking en de invoering van een aan de jeugd aangepast rechtssysteem moet in overeenstemming zijn met kinder- en mensenrechten.

Een comprehensief jeugddelinquentierechtssysteem heeft heropvoeding en herintegratie tot doel. Er wordt rekening gehouden met de leeftijd van de betrokkene. De reactie op het begane feit moet in verhouding staan tot de ernst van de feiten én tot de persoonlijke context van de pleger.

4. Dit onderdeel is een ingekorte en aangevulde versie van Kenniscentrum Kinderrechten, Beleidsadvies op eigen initiatief 2017-1. Voorontwerp van decreet jeugddelinquentierecht en het kinderrechtenkader. Toetsing van het voorontwerp aan het kinderrechtenluik binnen de Omgevingsanalyse Jeugdrecht (2015), 2017, www.keki.be/nl/ publications/beleidsadvies, 4-6. Hierna KeKi Beleidsadvies Voorontwerp decreet jeugddelinquentierecht.

5. Zie meer uitgebreid over het Belgische jeugdstrafrecht: B. de Smet, Het jeugddelinquentierecht in Vlaanderen, Antwerpen: Intersentia 2019; J. Put \& J. Leenknecht (red.), Het Vlaamse jeugddelinquentierecht, Brussel/Gent: Larcier 2019.

6. Kenniscentrum Kinderrechten, 'Reflectietekst Kinderrechten', Gent Kenniscentrum Kinderrechten, 2012, www.keki.be/sites/default/files/ 2012\%2006\%20reflectietekst\%20kinderrechten.pdf, 19 pagina's.

7. Kinderrechtencommissariaat, Advies nr. 2017-2018/2, Naar een jeugddelinquentierecht met sterke rechtswaarborgen voor de minderiarige, Brussel, Vlaams Parlement, 10 november 2017, www.kinderrechten commissariaat.be/advies/naar-een-jeugddelinquentierecht-met-sterkerechtswaarborgen-voor-de-minderjarige.

8. Voor een eerste overzicht zie:

- Rapport Kinderrechtelijk kader Omgevingsanalyse Jeugdrecht 2015:

- $\quad$ Sinds 2016 is er de Europese Richtlijn 2016/800 van 11 mei 2016 betreffende procedurele waarborgen voor kinderen die verdacht of beklaagd zijn in een strafprocedure (www.kekidatabank.be/ index.php?|vl=notice_display\&id=3007). Deze richtlijn is, gezien het moment van de opmaak van het rapport, niet verwerkt in het overzicht, maar de Vlaamse regering werd wél hierop gewezen en aangeraden dit mee te nemen in het politieke proces van de opmaak van het decreet: Aanbeveling 1.2. KeKi Beleidsadvies Voorontwerp decreet jeugddelinquentierecht;

- $\quad$ M. Rom, K. Herbots \& J. Put, De rechtspositie van jongeren in detentie in een (inter)nationaal perspectief, Leuven, Instituut voor Sociaal Recht, KU Leuven, 2009, 222 pagina's, www.law.kuleuven.be/isr/onderzoekoud/

onlinerapportenbijlagen/Eindrapport-\%20jongeren \%20in

\%20detentie-2009\%20beveiligd.pdf. Hierna Onderzoeksrapport Rechtspositie Jongere in Detentie 2009.
Dit jeugdrechtssysteem strekt zich uit tot alle personen onder een bepaalde maximumleeftijd. Dit is bij voorkeur de meerderjarigheidsgrens, namelijk 18 jaar. Het optrekken van deze maximumleeftijd wordt angeraden. Dit valt samen met de wetenschappelijke vaststellingen van de verschuivingen in de adolescentie van jongeren ('emerging adulthood'). ${ }^{9}$ Het hanteren van dubbele leeftijden wordt afgeraden en als discriminerend beschouwd. De minimumleeftijd voor strafrechtelijke verantwoordelijkheid is bij voorkeur minstens 12 jaar.

Een comprehensief en integraal jeugddelinquentierechtssysteem bewandelt minstens twee grote interventiemegen. Dit is vooreerst een buitengerechtelijke afhandeling (diversie, herstelrecht ...), waarbij voornamelijk in de gemeenschap naar oplossingen wordt gezocht. Deze weg moet steeds worden overwogen en openstaan voor alle minderjarigen en alle mogelijke feiten. Het kan dus niet worden beperkt tot lichtere feiten en/of 'first offenders'. Daarnaast kent het systeem een gerechtelijke afhandeling. Hier valt de waaier an mogelijke maatregelen uiteen in twee groepen: de niet-vrijheidsberovende en de vrijheidsberovende interventies. Er moet voldoende aanbod aan niet-vrijheidsberovende maatregelen zijn, zodat vrijheidsberoving effectief het laatste redmiddel is en voor de kortst mogelijke duur kan worden opgelegd. Daarnaast moet er ruimte zijn voor preventie en bestuurlijke interventies.

Het kind of de jongere die in anraking komt met het jeugd(delinquentie)rechtssysteem geniet naast de algemene mensen- en kinderrechten die steeds onverkort gelden (waaronder onderwijs, gezondheidszorg) specifieke rechts- en proceswaarborgen. Ook de ouders en wettelijke vertegenwoordigers genieten, als eerste opvoedingsverantwoordelijkheden, een aantal rechten en rechtswaarborgen.

Een comprehensief jeugddelinquentierechtssysteem wordt gedragen door een verscheidenheid aan gespecialiseerde, bekwame en permanent bijgeschoolde actoren, die de kinder- en mensenrechten niet enkel kennen, maar er ook naar handelen. Deze actoren vormen een weerspiegeling van de diversiteit onder hun cliënten (op vlak van gender, etniciteit, geloof ...).

Het is belangrijk dat de overheid actuele, voldoende, naumkeurige en gecoördineerde dataverzameling organiseert. Dit moet onderzoek toelaten over de aard, de omvang en de evolutie van jeugddelinquentie en over de uitvoering, de impact en het effect van de verschillende soorten interventies.

Een jeugddelinquentiesysteem, ten slotte, is onlosmakelijk verbonden met het nationaal ontwikkelingsproces dat

9. Zie ook de rapporten 1. Analyse Vlaamse context en 2. Jeugddelinquentie: Fenomenen en Verklaringen in Omgevingsanalyse Jeugdrecht, uitgevoerd door KU Leuven, UGent, Vrije Universiteit Brussel en Kenniscentrum Kinderrechten, in opdracht van het Agentschap Jongerenwelzijn, 374 pagina's. Het volledige rapport en de bijhorende samenvattende presentatie is vrij beschikbaar via: https://wvg.vlaanderen.be/ jongerenwelzijn/nieuws/2015/10/14/traject-jeugdrecht/, www.keki. $\mathrm{be/nl/onderzoeksthemas/justitie-en-jeugdhulp} \mathrm{en} \mathrm{www.law.ku}$ leuven.be/isr/omgevingsanalyse-volledig-rapport-1. Hierna Omgevingsanalyse Jeugdrecht 2015. 
elk land doormaakt op het vlak van jeugdhulpverlening, armoedebestrijding, meer humane justitie enz.

Rekening houdend met bovenstaande internationaal gestelde minimumvereisten werd België door het $V N$ Comité voor de Rechten van het Kind op enkele vlakken (herhaaldelijk) aangesproken. De landenrapporten van het comité maken, in tegenstelling tot de rechtspraak van het EHRM, geen inherent onderdeel uit van de desbetreffende bepalingen in het Kinderrechtenverdrag, noch zijn ze juridisch afdwingbaar. Toch getuigen deze landenrapporten van een hoge morele waarde op internationaal niveau en vormen ze een belangrijke graadmeter over de stand van zaken van implementatie, naleving, toepassing en vertaling van kinderrechten in nationaal beleid en de samenleving in zijn geheel.

\section{Het proces naar een Vlaams Jeugddelinquentiedecreet}

De Vlaamse aanpak van jeugddelinquentie, en de daarbij horende ambitie van een internationaal toonbeeld te zijn van good practice, beoordelend vanuit een kinderrechtenperspectief, veronderstelt oog te hebben voor beide: de decretale inschrijving van kinderrechten én de achterliggende geest van waaruit wordt omgegaan met kinderen en jongeren die een jeugddelict begaan, of hiervan verdacht worden. Hieronder komt het doorgelopen proces van de opmaak van het decreet aan bod. Een meer inhoudelijke toets van het decreet aan de kinderrechten volgt in het volgende hoofdstuk.

De uittekening van een Vlaams decreet over het omgaan met kinderen en jongeren die strafbare feiten plegen, doorliep een diepgaand proces. Bekeken vanuit een kinderrechtenperspectief ging, afhankelijk van de procesfase en de betrokken actoren, de aandacht in meerdere of mindere mate uit naar de juridische en/of maatschappelijke betekenis van kinderrechten.

Naast een traditioneel politiek debat kenmerken eveneens wetenschappelijke en maatschappelijke besprekingen de opmaak van het Vlaams Jeugddelinquentiedecreet. Vlaanderen ging, onder leiding van het Agentschap Jongerenwelzijn, ${ }^{10}$ met beleidsmedewerkers, onderzoekers, professionele actoren, jongeren en ouders in dialoog over jeugdrecht om zo prioriteiten, noden, verzuchtingen en wensen te verwerken in een geambieerd evidence based ${ }^{11}$ jeugddelinquentierecht.

10. Samen met het Agentschap Kind \& Gezin, is het Agentschap Jongerenwelzijn in 2019 gefusioneerd tot een nieuw Agentschap Opgroeien: Decreet van 1 maart 2019 tot ontbinding van het Fonds Jongerenwelzijn en tot wijziging van het decreet van 30 april 2004 tot oprichting van het intern verzelfstandigd agentschap met rechtspersoonlijkheid Kind en Gezin en het decreet van 12 juli 2013 betreffende de integrale jeugdhulp, BS 8 april 2019

11. Beleidsnota 2014-2019 Welzijn, Volksgezondheid en Gezin, ingediend door de heer Jo Vandeurzen, Vlaams Minister van Welzijn, Volksge-
Ter voeding van dit proces bracht in 2015 een consortium van Vlaamse universiteiten (KU Leuven, Universiteit Gent en Vrije Universiteit Brussel) in samenwerking met het Kenniscentrum Kinderrechten, de meest recente wetenschappelijke inzichten omtrent jeugddelinquentie in kaart via het onderzoeksrapport Omgevingsanalyse Feugdrecht. Naast de analyse van de Vlaamse context, de etiologie van jeugddelinquentie, een (inter)nationale evaluatie van de maatregelen en een algemeen vergelijkende studie van jeugdrechtsystemen in een aantal Europese landen of regio's ging de aandacht in de Omgevingsanalyse Feugdrecht ook uit naar het kinderrechtelijk kader. ${ }^{12}$ Dit laatste deelrapport geeft in de eerste plaats invulling aan de juridische betekenis van kinderrechten. De maatschappelijke betekenis van kinderrechten kwam voornamelijk in de overige rapporten aan bod.

Het daarna volgend Traject Jeugdrecht kenmerkt zich door dialoog over een aantal beslissende uitgangspunten bij de aanpak van jeugddelinquentie. Naast experten, beleidsmedewerkers, professionele actoren en ouders, werden ook jongeren met een jeugddelinquentieverleden in de dialoog betrokken. Ruimte voor eigen inbreng en aanvullingen werd geboden. ${ }^{13}$ Kinderen en jongeren konden op die manier een actieve rol opnemen in het invullen van het steeds zoekende evenwicht naar bescherming en verantwoordelijkheid. Dat is wat kinderrechten zijn.

Vervolgens doorliep het ontwerpdecreet het klassieke politieke proces met bespreking in de Vlaamse regering, herwerkingen van het ontwerp mede op basis van opgevraagde of ingestuurde adviezen door justitiële, welzijns- en kinderrechtenorganisaties en na derde goedkeuring overgezonden naar het Vlaams Parlement, waar het ontwerp opnieuw voorwerp werd van bespreking, opgevraagde advisering en ten slotte een definitieve goedkeuring ervan. ${ }^{14}$ In deze fase kwam vooral de juridische betekenis van kinderrechten op de voorgrond. zondheid en Gezin, www.vlaanderen.be/nl/publicaties/detail/ beleidsnota-2014-2019-welzijn-volksgezondheid-en-gezin.

12. Omgevingsanalyse Jeugdrecht 2015.

13. Zowel bij de startvergadering op 13 oktober 2015 als bij ieder rapport van de zes werkgroepen werd de inbreng van kinderen en jongeren apart en dus visueel zichtbaar opgenomen: https://wvg.vlaanderen.be/ jongerenwelzijn/over-ons/regelgeving/traject-jeugdrecht/ en https:// wvg.vlaanderen.be/jongerenwelzijn/nieuws/2015/10/14/trajectjeugdrecht/.

14. Ontwerp van decreet betreffende het jeugddelinquentierecht van 22 december 2017, Parl.St. VI.Parl. 2017-18, nr. 1670. 


\section{De zoektocht naar een kinderrechtenperspectief in het Jeugddelinquentie- decreet}

Een analyse van het Jeugddelinquentiedecreet tegen de achtergrond van het internationaal kinderrechtenkader en de specifieke opmerkingen in het Belgisch landenrapport van het VN-Comité voor de Rechten van het Kind legt de vertaling van kinderrechten bij jeugddelinquentie op Vlaams niveau bloot. ${ }^{15}$

\subsection{Het kader en de fundamentele uitgangspunten van het Jeugddelinquentiedecreet}

Vlaanderen heeft keuzes gemaakt in de aanpak van jeugddelinquentie en legt uit op welke principes het deze grondt. Veel van deze keuzes en principes vinden een decretale neerslag (art. 3 tot 6 ) of worden toegelicht tijdens parlementaire besprekingen. ${ }^{16}$ Vlaanderen wil zo aantonen waar het voor staat in het omgaan met jeugddelinquentie, waarop ze inzet en hoe ze dit aanpakt.

Een aantal principiële uitgangspunten roept vanuit een kinderrechtenperspectief onmiddellijk een voorbehoud op, zoals het behoud van de uithandengeving (art. 5 en 38) en de verantwoordelijkheid van de jongere (art. 3, par. $\left.1,1^{\circ}\right)$. Andere keuzes lijken zich in te schrijven in het kinderrechtenkader, waaronder inbouw van kwaliteitseisen en rechtswaarborgen (art. 3, par. 1, $2^{\circ}$, art. 3, par. $2,1^{\circ}$ en $5^{\circ}$, art. 3 , par. 3 en art. 3 , par. 5) en het afgescheiden traject met de jeugdhulp (art. 3, par. $1,2^{\circ}$ ).

\subsection{Een jeugddelinquentierechtssysteem met algemene eerbiediging en naleving van internationale kinder- en mensenrechteninstrumenten}

Het ontwerp van decreet bevat een kind- en jongereneffectrapport (JoKER) ${ }^{17}$ hoewel dit bij de eerste voorontwerpbespreking op de Vlaamse regering ${ }^{18}$ niet nodig werd geacht. Onder meer het Kenniscentrum Kinderrechten ${ }^{19}$ en de Raad van State ${ }^{20}$ stelden dit ontbreken van een JoKER aan de kaak. Een JoKER peilt naar de effecten van een voorgenomen nieuwe regelgeving op kinderen en jongeren jonger dan 25 jaar, waarbij ook mogelijke alternatieven voor de voorgestelde beslissing

15. Het KeKi Beleidsadvies Voorontwerp decreet jeugddelinquentierecht en de twee adviezen over het voorontwerp (advies 2017-2018/2) en het ontwerp van het jeugddelinquentierecht ( - aanvullend - advies 2018-2019/3) van het Kinderrechtencommissariaat vormen de grondslag van dit hoofdstuk. De adviezen zijn vrij raadpleegbaar op respectievelijke sites van deze instanties

16. Commissieverslag, 6-15

17. Als Bijlage bij de MvT, Parl.St. VI.Parl. 2017-18, nr. 1670/1, 415-427.

18. Nota aan de Vlaamse Regering betreffende het Voorontwerp van decreet betreffende het jeugddelinquentierecht, VR 20171407 DOC. 0759/1TER, 19

19. KeKi Beleidsadvies Voorontwerp decreet jeugddelinquentierecht, 10.

20. Advies RvS voorontwerp Jeugddelinquentiedecreet, 249, nr. 27 moeten worden beschreven. De vier leidende beginselen van het Kinderrechtenverdrag, met name non-discriminatie (art. 2), belang van het kind (art. 3), recht op leven, overleven en ontwikkeling (art. 6) en participatie (art. 12), vormen het kader. ${ }^{21} \mathrm{Bij}$ de probleembeschrijving in de JoKER moet worden verwezen naar het Vlaamse, federale, nationale, Europese en/ of internationale (bindende) kinderrechteninstrumentarium. ${ }^{22}$

Met de aanname van het Jeugddelinquentiedecreet bedt Vlaanderen een aantal internationale rechten en verplichtingen decretaal in. Zo bevat het decreet een aantal expliciete verwijzingen naar het Kinderrechtenverdrag, de Grondwet en het Decreet Rechtspositie Minderjarigen. In de memorie van toelichting bij het ontwerp van decreet wordt onder de hoofding 'Rechtswaarborgen en kwaliteitseisen' verwezen naar het Europees Verdrag voor de Rechten van de Mens, de Grondwet en de Europese regels van Childfriendly Fustice. ${ }^{23}$

De verwijzing naar specifieke instrumenten is echter eerder selectief. Zo verwijst de memorie van toelichting niet naar de rechtswaarborgen die door het Kinderrechtenverdrag worden bepaald, die nochtans van dwingend recht zijn. Evenmin wordt in de memorie, noch in het decreet melding gemaakt van de Richtlijnen die door de Verenigde Naties specifiek met betrekking tot jeugddelinquentie zijn uitgevaardigd (cf. Bejing, Riyadh en Tokyo Rules) of enig andere Europese instrumenten, zoals de Europese Richtlijn 2016/800 van 11 mei 2016 betreffende procedurele waarborgen voor kinderen die verdacht of beklaagd zijn in een strafprocedure. Enerzijds doet dit de vraag rijzen in hoeverre het Vlaamse jeugddelinquentierecht zich expliciet inschrijft in specifiek voor de aanpak van jeugddelinquentie toepasselijke kinder- en mensenrechteninstrumenten. Anderzijds riskeert een opsomming steeds onvolledig te zijn met risico op gedateerdheid, omdat het instrumentarium steeds in beweging is. De huidige schemerzone draagt alleszins niet bij tot het zichzelf tillen tot een internationaal toonbeeld op het vlak van het omgaan met jeugddelinquentie.

Iedere jongere die in anraking komt met het gerecht omwille van het (vermoeden van het) plegen van strafbare feiten ontvangt de toepasselijke artikelen uit het Kinderrechtenverdrag (art. 3, par. 3). De overhandiging van verdragsartikelen aan de betrokken jongeren is een eerste stap in het hen wijzen op hun rechten. Samen gelezen met artikel 3 , par. $1,2^{\circ}$, waarin verwijzing naar de geldende norm en de uitleg van de procedure in een voor de jongere begrijpelijke taal als een grondbeginsel wordt ingeschreven, leggen deze artikelen aan iedere actor de verplichting op tot duiding en omzetting van verdragsteksten in een begrijpbare, toegankelijk, ver-

21. Art. 4 Decreet 20 januari 2012 houdende een vernieuwd jeugd- en kinderrechtenbeleid, BS 7 maart 2012

22. Vlaamse Overheid-Departement Cultuur, Jeugd en Media, 'Handleiding JoKER. Handleiding voor de opmaak van een kind- en jongereneffectrapport (JoKER)', 12 oktober 2017, 9.

23. MvT, 20 
staanbare en aangepaste taal. Een kindvriendelijke en kindaangepaste versie van de verdragsartikelen met de nodige duiding en omkadering ligt in de lijn van artikel 42 Kinderrechtenverdrag en de Guidelines of the Committee of Ministers of the Council of Europe on child-friendly justice (2010), waartoe Vlaanderen zich uitdrukkelijk heeft verbonden. Zo niet, riskeert deze afgifte van artikelen zijn doel te missen.

\subsection{Kwaliteitsvol en comprehensief jeugddelinquentierecht}

Wil een Vlaams jeugddelinquentierecht volgens de internationale standaarden kwaliteitsvol en comprehensief zijn, dan moet het voldoen aan de hierna volgende kinderrechtelijke vereisten.

\subsubsection{Specifieke regelgeving voor kinderen en jongeren, met een minimum - en maximumleeftijdsgrens}

- $\quad$ Minimumleeftijd van strafrechtelijke verantwoordelijkheid

Over de minimumleeftijd waaronder kinderen niet in staat worden geacht een strafbaar feit te begaan, is geen internationale noch Europese consensus. Het Kinderrechtenverdrag beperkt zich ertoe lidstaten aan te bevelen om wettelijk een minimumleeftijd voor strafrechtelijke verantwoordelijkheid vast te leggen (art. 40.3 Kinderrechtenverdrag). Waar het VN-Comité voor de Rechten van het Kind in zijn (inmiddels vervangen) Algemene Commentaar nr. 10 uit 2007 over kinderrechten in het jeugdrechtssysteem nog de leeftijd van 12 jaar als minimum voor strafrechtelijke verantwoordelijkheid naar voren schoof, ${ }^{24}$ stelt het nu in het (ter vervanging van het Algemene Commentaar nr. 10) Algemene Commentaar nr. 24 voor om dit op te trekken tot 14 jaar. $^{25}$

De decreetgever heeft de keuze gemaakt om de leeftijd van 12 jaar als ondergrens te nemen voor zijn strafrechtelijke verantwoordelijkheid. Een persoon jonger dan 12 jaar wordt onweerlegbaar vermoed niet strafrechtelijk verantwoordelijk te zijn (art. 4, par. 2). Hij komt zo tegemoet aan de huidige richtsnoer van het VN-Comité voor de Rechten van het Kind.

- Maximumleeftijd voor de toepasselijkheid van een jeugd(delinquentie)recht

De bovengrens voor de toepasselijkheid van het jeugddelinquentierecht in het nieuwe decreet is 18 jaar (art. 2, $7^{\circ}$ en $10^{\circ}$ en art. 4 , par. 1). Dit valt samen met de bovengrens van het persoonlijk toepassingsgebied van het Kinderrechtenverdrag (art. 1) en met de definitie van wat onder 'jeugd' moet worden verstaan (regel 11.a Havana Rules). Ook andere internationale regelgeving

24. VN-Comité voor de Rechten van het Kind, Algemeen Commentaar nr. 10 (2007) van 25 april 2007 - Children's rights in Juvenile Justice, www.kekidatabank.be/index.php?|v|=notice_display\&id=249, para. 32. Hierna Algemene Commentaar nr. 10.

25. VN-Comité voor de Rechten van het Kind, zie par. 22 van General Comment No. 24 Children's rights in the child justice system, https:// tbinternet.ohchr.org/_layouts/15/treatybodyexternal/Download.aspx? symbolno=CRC $\% 2 f C \% 2 f G C \% 2 f 24 \&$ Lang=en. Hierna Commentaar nr. 24. hanteert 18 jaar als maximumleeftijd voor de toepasselijkheid van een jeugd(delinquentie)rechtssysteem. ${ }^{26}$

Delicten gepleegd door een jongere voor de leeftijd van 18 jaar komen dus in aanmerking voor een reactie zoals vervat in het decreet. Ook als de persoon op minderjarige leeftijd een jeugddelict pleegde, maar intussen ouder dan 18 jaar is geworden, kan het Openbaar Ministerie de zaak nog aanhangig maken bij de jeugdrechtbank zodat deze, bij een gegronde vordering, een sanctie kan opleggen, ook na de meerderjarigheid (art. 28).

In bepaalde omstandigheden wordt deze maximumleeftijdsgrens echter naar beneden gehaald, met name tot 16 jaar. Jongeren binnen de leeftijdsvork van 16 tot 18 jaar die een jeugddelict plegen, kunnen, mits vervulling van een aantal voorwaarden, weggeleid worden uit het jeugddelinquentierecht met het oog op vervolging binnen het gemeen strafrecht. Deze jongeren kunnen dus als volwassenen worden berecht (art. 36). ${ }^{27}$ In de memorie van toelichting wordt deze keuze verantwoord vanuit het idee dat bij bepaalde minderjarigen die in een asociale gedragslijn zijn vastgeroest, het opleggen van een sanctie vanuit het jeugddelinquentierecht ontoereikend kan zijn. ${ }^{28}$

Door de praktijk van uithandengeving te behouden, kiest Vlaanderen er uitdrukkelijk voor om het Belgische beleid van dubbele leeftijdsgrenzen te behouden. De praktijk van uithandengeving baart vanuit kinderrechtenperspectief het VN-Comité voor de Rechten van het Kind al twintig jaar ernstige zorgen. Ze wordt als discriminerend beschouwd en is niet in overeenstemming met de kinderrechten. Uithandengeving opent de deur naar het sanctioneren van minderjarigen als volwassenen, wat tegen artikel 40 van het Kinderrechtenverdrag ingaat. De voorbije vier keer dat België zijn landenrapport indiende bij het VN-Kinderrechtencomité, werd België steeds aangemaand het systeem van uithandengeving af te schaffen (zie ook verder, afdeling 5).

Nochtans is in het huidige decreet een langdurige bestraffing van de jongere, ook na zijn meerderjarigheid, mogelijk. Bij het plegen van zeer ernstige delicten is immers een sanctie van gesloten begeleiding mogelijk voor een maximale duur van twee, vijf of zeven jaar. Dit betekent dat een jongere kan worden opgesloten tot de leeftijd van 25 jaar (art. 37). De sanctie kan alleen tijdens de rechtspleging ten gronde worden opgelegd wan-

26. Zie bijv. par. 29 Algemene Commentaar nr. 24 (maar zie ook par. 32, waarin verdragstaten met een hogere maximumleeftijd dan 18 jaar worden geprezen); art. 21.1 Recommendation $\operatorname{Rec}(2008) 11$ of the Committee of Ministers of the Council of Europe on the European Rules for juvenile offenders subject to sanctions or measures (hierna ERJ) en overweging 1 en art. 2 Richtlijn (EU) 2016/800.

27. De procedurele garanties vervat in de Europese Richtlijn 2016/800 is specifiek ook op deze uithandengegeven jongeren van toepassing, waaronder recht op bijstand advocaat (art. 6) en professionele actoren die een specifieke opleidingen genieten/hebben genoten (art. 20.3 en overweging $63^{\circ}$ ). Zie ook verder in deze afdeling onder par. 4.3.5. Gespecialiseerde actoren. Deze resolutie moet tegen 11 juni 2019 naar Belgisch recht zijn omgezet.

28. MvT, 67 
neer er cumulatief is voldaan aan zes voorwaarden (art. 37, par. 2). Bovendien kan de jeugdrechtbank onder strikte voorwaarden de sanctie van langdurige gesloten begeleiding combineren met een terbeschikkingstelling van de jeugdrechtbank voor een maximale duur van tien jaar, na het einde van de sanctie. Het decreet bepaalt de cumulatieve voorwaarden waaronder een terbeschikkingstelling kan worden uitgesproken (art. 37, par. 8). Dit betekent dat de sanctie die een minderjarige opgelegd krijgt - bij zeer ernstige misdrijven - maar liefst zeventien jaar kan duren. Vanaf de leeftijd van 25 jaar wordt - bij een terbeschikkingstelling - het dossier overgemaakt aan de strafuitvoeringsrechtbank voor volwassenen.

Nog los van de vraag of met de mogelijkheid van terbeschikkingsstelling de slinger van mogelijke langdurige bestraffing niet al te ver doorslaat, wordt wel duidelijk dat met de invoering van de langdurige bestraffing het behoud van de mogelijkheid tot uithandengeving elke grond mist. Volgens de memorie van toelichting is deze langdurige sanctie immers een antwoord vanuit de Vlaamse gemeenschap op de figuur van de uithandengeving. ${ }^{29}$ De bepalingen van gesloten plaatsing en terbeschikkingstelling zijn een meer dan volwaardig alternatief voor de uithandengeving, zodat vanuit kinderrechtenperspectief de keuze om de figuur van uithandengeving te behouden moeilijk te begrijpen is.

Door het behoud van de uithandengeving ondergraaft de Vlaamse Regering haar eigen ambities. Vlaanderen mist een unieke kans om zich op internationaal toneel als toonvoorbeeld te profileren met een coherent en allesomvattend jeugddelinquentierecht, dat een waaier van antwoorden biedt op alle jongeren onder de 18 jaar die een strafbaar feit plegen, van welke aard, ernst en zwaarte dan ook. Hetzelfde geldt overigens voor de verkeersmisdrijven, waar het decreet de wettelijke uitzondering van de verwijzing van de 16-jarige pleger van een verkeersdelict naar de politierechtbank bevestigt.

\subsubsection{Heropvoeding en herintegratie tot doel}

- Het moeilijke evenwicht tussen re-integratie van de jongere en de bescherming van de maatschappij Het jeugddelinquentierechtssysteem dient rekening te houden met de wenselijkheid van het bevorderen van de herintegratie en de rehabilitatie van de jongere en van de aanvaarding door de jongere van een opbouwende rol in de samenleving (art. 39 en 40.1 Kinderrechtenverdrag; art. 14 BUPO-Verdrag). Tijdens een procedure wordt rekening gehouden met de leeftijd van de jongere en de wenselijkheid van reclassering (art. 40 Kinderrechtenverdrag; art. 14.4 BUPO-Verdrag).

De grondbeginselen van het decreet en de geest waarin het Jeugddelinquentiedecreet moet worden gelezen en uitgevoerd, worden in artikel 3 ten overstaan van de actoren (par. 1), het optreden (par. 3), de minderjarige (par. 4) en de ouders/opvoedingsverantwoordelijken (par. 5) uitgetekend.

Deze grondbeginselen verwijzen naar elementen van preventie (van recidivisme), opvoeding en sociale reintegratie. In deze optiek verwijst het Jeugddelinquentiedecreet naar het welzijn van de jongere als premisse.

Echter, tegelijkertijd verwijzen de grondbeginselen ook onder meer naar een 'bescherming van het veilig en vredig samenleven in de maatschappij' en 'vermijden van recidive ter bescherming van de maatschappij op lange termijn'. Dit zijn terechte bekommernissen van de maatschappij, maar in het licht van heropvoeding en reintegratie mag de balans niet zuiver overhellen naar het veiligheidsperspectief.

Het decreet kiest voor een aanpak die expliciet vertrekt vanuit de individuele verantwoordelijkheid van de jongere. ${ }^{30}$ De aandacht voor herstel en bemiddeling en de belofte om beide goed te ondersteunen, maken duidelijk dat de decreetgever alle kansen wil geven aan jongeren die hun verantwoordelijkheid willen opnemen. De jongere krijgt ruimte om, samen met zijn ouders en een ondersteunende dienst, de schade te herstellen.

Het gevaar dreigt echter dat er met de individuele verantwoordelijkheid van de jongere op een te geïsoleerde wijze wordt omgesprongen. Bij de uitvoering van het decreet zal erover moeten worden gewaakt dat het precaire evenwicht tussen de doelstelling van heropvoeding en integratie in het belang van de minderjarige enerzijds en de belangen van het slachtoffer en de maatschappij anderzijds worden gewaarborgd. De jongere moet immers via het jeugddelinquentierecht de kans krijgen om een opbouwende rol in de samenleving op te nemen en op een volwaardige manier aan de samenleving deel te nemen. Dit is in het belang van de betrokken jongere én de samenleving.

- Delictgericht werken met de ouders

Het Kinderrechtenverdrag stelt dat de ouders de eerste opvoedingsverantwoordelijken zijn, spreekt de overheid aan om de ouders te ondersteunen in het opnemen van hun verantwoordelijkheid (art. 5) en erkent de positie van de ouders in de aanpak van jeugddelinquentie (art. 40.2 , b, ii en iii).

Ook het Jeugddelinquentiedecreet erkent de plaats van de ouders of de opvoedingsverantwoordelijken. Bij elke beslissing worden ze betrokken. De procureur des Konings stuurt ze een kopie van zijn schrijven of roept ze op (art. 9-13) en de jeugdrechter betrekt ze op een actieve wijze als hij maatregelen of sancties aan de jongere oplegt (art. 15, par. 3). Er wordt ook uitdrukkelijk bepaald dat ouders en opvoedingsverantwoordelijken na een 'gesloten begeleiding' van de minderjarige op ondersteuning en begeleiding kunnen rekenen (art. 17, par. 2).

30. MvT, 5; Commissieverslag, 7. 
Het uitspreken van een maatregel of een sanctie tegenover een jongere kan worden gecombineerd met het opleggen van delictgericht werken met de ouders of opvoedingsverantwoordelijken. Samen en met de hulp van een onpartijdige tussenpersoon moet alzo onder meer aan de relationele en materiële gevolgen van een jeugddelict tegemoet worden gekomen en de breuken hersteld worden (art. 18, par. 1).

Effectieve ondersteuning en begeleiding van ouders kan zeer zinvol zijn, voor zover dit synoniem staat aan 'ondersteuning' en niet als 'sanctionering'. De praktijk zal moeten uitwijzen hoe dit delictgericht werken met de ouders concreet zal worden ingevuld.

\subsubsection{Minstens twee grote interventiemegen: buitengerechtelijk en gerechtelijk, met elk een brede waaier a an reactiemogelijkheden}

- $\quad$ Buitengerechtelijke afhandeling

Wanneer dit passend en wenselijk is, moet de reactie op strafbaar gesteld gedrag kunnen worden afgehandeld buiten de gerechtelijke weg om, zo stelt het Kinderrechtenverdrag. Ook hier dienen steeds de kinderrechten en de rechtswaarborgen volledig te worden geëerbiedigd (art. 40.3.b). Het VN-Comité voor de Rechten van het Kind tekent de krijtlijnen uit van een buitengerechtelijke afhandeling. Ook binnen deze fase moeten de kinderrechten en rechtswaarborgen, zoals bepaald in artikel 40 Kinderrechtenverdrag, gerespecteerd blijven. Nadruk wordt onder meer gelegd op verbod van dwang of intimidatie, vrijwillige instemming na volledige en afdoende informatie, verbod van gebruik van erkenning van schuld in een volgende procedure, recht op (rechts)bijstand, ouderlijke betrokkenheid, mogelijkheid tot beroep, ingeschreven in de wet, net als de eventuele bevoegdheid van politie, openbaar ministerie of andere besturen om hierin op te treden en beëindiging van de maatregel tot definitieve afsluiting van de zaak. ${ }^{31}$

Het Jeugddelinquentiedecreet trekt resoluut de kaart van de buitengerechtelijke afhandeling, in die zin dat het jeugddelinquentierecht nu zelfs voorrang geeft - 'wanneer dit mogelijk is' - aan de afhandeling op het niveau van het Openbaar Ministerie (art. 3, par. 3, $3^{\circ}$ ).

De buitengerechtelijke afhandeling wordt in dit decreet echter verengd tot het Openbaar Ministerie als enige actor om 'buitengerechtelijk' te reageren op een jeugddelict. Het krijgt, als justitiële actor, bovenop het monopolie in vorderingsrecht (art. 14) eveneens de beslissingsmacht over buitengerechtelijke afhandeling.

Door 'buitengerechtelijk' in het decreet louter in te vullen op het niveau van het Openbaar Ministerie, ontstaat het risico dat Vlaanderen niet afdoende antwoord biedt op de vereiste van een comprehensief jeugddelinquentierecht, met inbegrip van buitengerechtelijke afhandeling, ook wel aangeduid als 'diversie' (o.a. art. 40.3.b

31. Par. 16-18 Algemene Commentaar nr. 24
Kinderrechtenverdrag). ${ }^{32}$ Hoewel het Kinderrechtenverdrag, noch andere kinderrechteninstrumenten een omvattende definitie bevatten, wordt wel verwezen naar een waaier aan actoren die als diversie of als een alternatief voor het opstarten van een gerechtelijke vervolging voor de jeugdrechter worden beschouwd. Voorbeelden hiervan zijn de familie, vrijwilligers, burgerrechtelijke of administratieve autoriteiten, school en andere instellingen en diensten binnen de samenleving. ${ }^{33}$ Bovendien is deze afhandeling voornamelijk gemeenschapsgeinspireerd, met maatregelen als gemeenschapsdienst, toezicht en begeleiding door sociale werkers, probatie-assistenten en herstelrechtelijke initiatieven. ${ }^{34}$

Positief aan de inbedding van het buitengerechtelijk aanbod in het decreet is dat interventiemogelijkheden op het niveau van het parket worden geëxpliciteerd, conform het legaliteitsbeginsel. De uitvoering van de door de procureur des Konings opgelegde voorwaarden wordt beperkt in de tijd, tot zes maanden (art. 11, par. 3 en 13 , par. 1 , lid $6,4^{\circ}$ ). Wanneer de voorwarden tot een goed einde worden gebracht, en/of wanneer het positief project conform de overeenkomst werd uitgevoerd, maakt de procureur des Konings hiervan een procesverbaal op en vervalt de strafvordering (art. 11, par. 4, lid 3, 12, par. 4 en 13, par. 2). Het decreet voorziet voor elke buitengerechtelijke afhandeling ook in de bijstand van een advocaat, zowel wanneer aan de minderjarige voorwaarden worden opgelegd, bij herstelbemiddeling als bij het voorstel om een positief project uit te werken.

In het decreet staat opgetekend dat, om in aanmerking te komen voor een buitengerechtelijke afhandeling, de minderjarige het delict niet mag ontkennen (art. 11, par. 1, 12, par. 1 en 13, par. 1). De voorwaarde 'het bestaan van ernstige aanwijzingen van schuld' blijft evenwel overeind alvorens door de procureur des Konings een aanbod tot bemiddeling kan worden gedaan (art. 12, par. 1, lid $4,1^{\circ}$ ). Het Grondwettelijk Hof oordeelde echter al in 2008 dat deze voorwaarde een schending was van het vermoeden van onschuld, ${ }^{35}$ waardoor de huidige formulering in het Jeugddelinquentiedecreet problematisch blijft.

Het ontbreken van controle op of enige beroepsmogelijkheid tegen het beleid en het handelen van het Openbaar Ministerie, roept vragen op. Als zogenaamde buitengerechtelijke actor, krijgt het Openbaar Ministerie wel veel macht, met verminderde rechtswaarborgen voor de jongere tot gevolg. Op het niveau van de rechtbank is er immers het recht van hoger beroep en het beginsel van dubbele aanleg.

32. Zie KeKi Beleidsadvies Voorontwerp decreet jeugddelinquentierecht, 13-15 en regel 2.2; Advies RvS amendementen Jeugddelinquentiedecreet, 5-6, nr. 2.2

33. Zie onder meer: art. 40, lid 3, b) Kinderrechtenverdrag, regel 1.3. Beijing Rules; par. 17 Algemene Commentaar nr. 24.

34. Zie onder meer: art. 40, lid 4 Kinderrechtenverdrag, regel 11.4 Beijing Rules, par. 17 Algemene Commentaar nr. 24, art. 12 ERJ en art. 11 Europese Richtlijn 2016/800.

35. GwH 13 maart 2008, nr. 49/2008 en nr. 50/2008. 
Tot slot verdient het aanbeveling om de actoren binnen het Openbaar Ministerie die zich met jeugdzaken bezighouden te erkennen als gespecialiseerde eenheid met vereisten op vlak van scholing en bekwaamheid (zie verder par. 3.4.5, gespecialiseerde actoren).

De buitengerechtelijke afhandeling staat bijgevolg op gespannen voet met het principe van de scheiding der machten, het toekennen van een te (?) ongebreidelde macht aan het openbaar ministerie, en het vermoeden van onschuld van de jongere.

\section{- $\quad$ Gerechtelijke afhandeling}

De gerechtelijke afhandeling van een (jeugd)delict moet in elk geval voldoen aan een antal internationaal aanvaarde beginselen, met name:

- het proportionaliteitsbeginsel: de reactie is steeds in verhouding tot de omstandigheden en de ernst van de feiten, de context en de noden van het betrokken kind of jongere en tot de noden van de samenleving: ${ }^{36}$

- het individualiteitsbeginsel: de leeftijd, het fysieke en mentale welzijn, de ontwikkeling, vaardigheden en persoonlijke omstandigheden van het kind of de jongere moeten door de rechter in rekening worden gebracht; ${ }^{37}$

- vrijheidsbeperkende maatregelen kunnen enkel na een zorgvuldige overweging en voor de kortst mogelijke duur,; 38

- vrijheidsberoving is slechts mogelijk bij een zwaar misdrijf met geweldpleging tegen een persoon, herhaald gepleegde zware misdrijven of wanneer er geen ander passend antwoord mogelijk is. ${ }^{39}$

Binnen de gerechtelijke afhandeling valt de waaier aan reacties uiteen in twee groepen: de niet-vrijheidsberovende en de vrijheidsberovende interventies. Een combinatie van reacties is mogelijk. Om de beslissing tot het opleggen van een reactie te nemen, wordt rekening gehouden met een aantal factoren, zowel persoons- als samenlevingsgerelateerd (art. 16, par. 1).

Ook bij een gerechtelijke interventie ligt de eerste focus op herstel, en naast herstelbemiddeling kan een aanbod van herstelgericht groepsoverleg worden gedaan (art. 20, par. 1 en art. 29, par. 1).

De reactie dient conform het proportionaliteitsprincipe altijd in verhouding te staan tot de ernst van de feiten en dat is ook de reden waarom deze factor als eerste beoordelingscriterium is vastgelegd.

De maximale duur van de reactie op een jeugddelict moet worden bepaald. Een verlenging van de duur van de reactie is niet mogelijk.

De jeugdrechter of de jeugdrechtbank kan wel, te allen tijde, ambtshalve of op vordering van het Openbaar Ministerie, de opgelegde maatregelen of sancties ten aanzien van de minderjarige herzien, intrekken of wijzi-

36. Regel 5.1 en 17.1.a Beijing Rules; regel 1 Havana Rules, par. 76 Algemene Commentaar nr. 24 en art. 5 ERJ.

37. Regel 17.1.d. Beijing Rules; art. 2.3 Tokyo Rules en art. 5 ERJ.

38. Regel 17.1.d. Beijing Rules; art. 2.3 Tokyo Rules en art. 5 ERJ.

39. Regel 17.1.c Beijing Rules. gen in een minder strenge of ingrijpende maatregel of sanctie (art. 16, par. 2). Deze toevoeging, die pas in de finale versie van het Jeugdelinquentiedecreet gebeurde, is voor de jongere van groot belang, gelet op het feit dat hij of zij in volle ontwikkeling is, en ook zijn context snel kan wijzigen. Het is belangrijk dat de jeugdrechter hier snel op kan inspelen.

Vrijheidsberoving wordt, rekening houdend met het subsidiariteitsprincipe, in het decreet naar voren geschoven als ultimum remedium, en dit zowel in de voorbereidende rechtspleging als in de fase ten gronde. Tegelijkertijd besteedt het decreet veel aandacht aan de decretale uitwerking ervan en wordt het toepassingsgebied verruimd.

De mogelijke duur van de vrijheidsberoving wordt, in vergelijking met de Jeugdbeschermingswet, verlengd, zowel in de voorbereidende rechtspleging als in de fase ten gronde.

Daar waar het voor een jongere in de voorbereidende rechtspleging in het verleden mogelijk was reeds na een gesloten begeleiding van 5 dagen opnieuw voor de jeugdrechter te verschijnen ${ }^{40}$ wordt nu steeds gestart met een maatregel van gesloten oriëntatie voor de maximale duur van één maand. Binnen tien dagen moet er een eerste oriëntatieverslag voohanden zijn, waarna binnen 48 uur een zitting volgt. In de praktijk zal de gesloten begeleiding dus wellicht steeds minimaal twaalf dagen duren (art. 26).

Gesloten begeleiding kan worden opgelegd als maatregel (maximaal drie maanden, hernieuwbaar, art. 27) of als sanctie (voor drie, zes of negen maanden, art. 36). In bepaalde omstandigheden kan een jongere gesanctioneerd worden met een gesloten begeleiding van twee, vijf of zeven jaar (art. 37). Deze sanctie kan niet langer duren dan tot de dag waarop de delictpleger de leeftijd van 25 jaar heeft bereikt.

Tot slot kan de jeugdrechtbank onder strikte voorwaarden de sanctie van langdurige gesloten begeleiding ook combineren met een terbeschikkingstelling van de jeugdrechtbank voor een maximale duur van tien jaar (art. 37, par. 8).

Het Jeugddelinquentiedecreet kiest dus voluit voor de mogelijkheid van langdurige vrijheidsberovende maatregelen voor jongeren die een delict hebben gepleegd.

$\mathrm{Bij}$ een vrijheidsberovende reactie moet re-integratie van de jongere in de samenleving bij gesloten begeleiding vanaf dag één het doel zijn. Er wordt in het Jeugddelinquentiedecreet niet geconcretiseerd op welke manier dit zal worden waargemaakt. De rol die toegang tot het onderwijs hierin moet spelen, is cruciaal. Bij reintegratie en positieve ontwikkeling van kinderen en jongeren is het hebben van een positief toekomstperspectief van groot belang. ${ }^{41}$ Recent werd nogmaals de

40. Wet 1 maart 2002 betreffende de voorlopige plaatsing van minderjarigen die een als misdrijf omschreven feit hebben gepleegd, BS 1 maart 2002.

41. R. Roose, L. Bradt, C. Vandekinderen \& K. De Vos, 'Rapport 1. Analyse Vlaamse context', in: Omgevingsanalyse Jeugdrecht 2015. 
moeilijke relatie tussen gesloten plaatsing van een jongere en zijn onderwijsloopbaan aan de kaak gesteld. Het onderwijsaanbod binnen de instellingen dient niet alleen breder te zijn, de door jongeren opgedane kennis moet ook buiten de instelling gevaliseerd worden. De aansluiting bij het reguliere onderwijs moet na een verblijf bovendien worden vergemakkelijkt. Nog al te vaak is een plaatsing in een instelling gelijk aan een 'pauzeknop op onderwijsvlak'. ${ }^{42}$ Het in artikel 28 en 29 Kinderrechtenverdrag en artikel 24 Grondwet gewaarborgde recht op onderwijs wordt bij jongeren die gesanctioneerd worden voor het plegen van strafbare feiten niet automatisch noch voldoende gewaarborgd. Er ligt voor Vlaanderen een belangrijke uitdaging om hieraan snel en afdoende tegemoet te komen.

Opvallend is bovendien dat de duurtijd van maatregelen en sancties is verzwaard of verhoogd. Zo kan de jeugdrechter in de voorbereidende fase aan de verdachte een leerproject opleggen van zestig uur (voorheen maximaal dertig uur) en ook de uitvoering van een gemeenschapsdienst werd verhoogd van dertig uur naar zestig uur. In de fase ten gronde worden deze sancties van leerproject of gemeenschapsdienst opgetrokken tot maar liefst 220 uur. Enige motivering over de noodzakelijkheid hiervan wordt niet teruggevonden. Rekening houdend met het gegeven dat een jongere een opgelegde niet-vrijheidsberovende reactie in de regel uitvoert in zijn vrije tijd, dus buiten de schooluren, kan het volledig doorlopen ervan verscheidene maanden tot zelfs meer dan een jaar duren.

Wil het optreden humaan, zinvol en zingevend zijn (art. 3 , par. $2,2^{\circ}$ ) en niet strenger of ingrijpender zijn dan gerechtvaardigd door het begane jeugddelict, de schade en het gevaar voor de maatschappij (art. 3, par. 2, $3^{\circ}$ ), moet bij het bepalen van het aantal uren rekening worden gehouden met de specifieke situatie (art. 3, par. $2,4^{\circ}$ ) en het grondbeginsel dat reacties voor een zo kort mogelijke duur worden genomen (art. 3, par. 5). Zoniet, komt het beginsel dat vrijheidsbeperkende matregelen enkel kunnen na een zorgvuldige overweging en voor de kortst mogelijke duur, zwaar onder druk te komen staan.

\subsubsection{Proces- en rechtswaarborgen}

Het toekennen van een eigen verantwoordelijkheid aan minderjarigen maakt een versterking van de rechtswaarborgen noodzakelijk. Het belang hiervan wordt geduid in de memorie van toelichting:

'[h]ierbij worden procedurele waarborgen, zoals principes van legaliteit, proportionaliteit, subsidiariteit, het vermoeden van onschuld, het recht op een eerlijk proces, het recht op juridische bijstand, het recht op toegang tot de rechtbank en het recht van beroep als te garanderen waarborgen naar voren geschoven. ${ }^{43}$

Het Jeugddelinquentiedecreet heeft doorheen het proces van de totstandkoming van het decreet gewerkt aan de

42. Commissie van Toezicht voor jeugdinstellingen, Jaarverslag 2018. Open venster op de gesloten jeugdinstellingen, 2019, 52 pagina's en www.kinderrechtencommissariaat.be/sites/default/files/bestanden/ presentatiejaarverslagcvtj_ingeschoevaerts_13maart2019.pdf.

43. MvT, 20; Verslag hoorzitting, 13. structurele inbedding van de proces- en rechtswaarborgen, waarbij de Europese Richtlijn 2016/800 als inspiratiebron diende.

De principes van proportionaliteit en subsidiariteit worden expliciet in het Jeugddelinquentiedecreet ingeschreven, en dit op verschillende plaatsen. De toepassing van deze principes zal duidelijk worden in de dagelijkse praktijk van de jeugdrechter, met name ook in hoe het opleggen van bepaalde maatregelen en sancties zal worden gemotiveerd.

Het Jeugddelinquentiedecreet voorziet steeds in gespecialiseerde bijstand van een advocaat, en dit niet alleen op het niveau van de jeugdrechtbank (art. 15, par. 2), maar ook op het niveau van het Openbaar Ministerie (art. 11, par. 2, 12, par. 1, lid 5, $1^{\circ}$ en art. 13, par. 1, lid 2). De minderjarige, die geen advocaat heeft, wordt altijd ambtshalve een toegewezen. In de praktijk zal de ambtshalve toegewezen advocaat ook altijd een opgeleide jeugdadvocaat zijn. Volgens de aanbeveling van de Orde van Vlaamse Balies wordt bij de ambtshalve aanstelling van de advocaat immers gekozen voor een advocaat die het certificaat 'bijzondere opleiding jeugdrecht' heeft behaald. ${ }^{44}$

Bedenkingen over de waarborgen zijn er vooral op het niveau van het legaliteitsbeginsel, dat inhoudt dat een strafbepaling voldoende precies en duidelijk moet worden geformuleerd. Dit is in het Jeugddelinquentiedecreet niet steeds het geval. Ook de uitbreiding van de bevoegdheden van het openbaar ministerie en bepaalde formuleringen in het Jeugddelinquentiedecreet omtrent het herstelrechtelijk aanbod staan op gespannen voet met het vermoeden van onschuld van de jongere (supra).

\subsubsection{Gespecialiseerde actoren}

Een belangrijke voorwaarde voor het welslagen van het Vlaamse jeugddelinquentierecht is dat het wordt gedragen en vorm gegeven door gespecialiseerde, bekwame en permanent bijgeschoolde actoren, werkzaam bij de politie, de magistratuur (staand en zetelend), de sociale dienst, de publieke en private voorzieningen, de advocatuur en andere personen die juridische of andere gepaste bijstand verzorgen. ${ }^{45}$ Een multidisciplinaire (bij)scholing met aandacht voor minstens juridische, psychologische, communicatieve en sociale invalshoeken is onontbeerlijk. De opleiding moet ook ingaan op specifieke noden van de meest gemarginaliseerde groepen. ${ }^{46}$ Ook voor juridisch geschoolde actoren is een juridische vorming noodzakelijk, aangezien kinderrechten, jeugdhulprecht, jeugddelinquentierecht en welzijnsrecht tijdens

44. Aanbeveling OVB 7 december 2005.

45. Zie onder meer art. 4, par. 106-108 Algemene Commentaar nr. 24; regel 6.3 en 22 Beijing Rules; regels 80-87 Havana Rules; regels 13.2 en 15 Tokyo Rules en overweging 63 en art. 20 Europese Richtlijn 2016/800.

46. Zie onder meer regel 1.6 en 22.1 Beijing Rules; regel 85 Havana Rules; regel 15-16 Tokyo Rules; art. 129 ERJ; par. 39 Algemene Commentaar nr. 24 en overweging 63 Europese Richtlijn 2016/800. 
de basisopleiding in de rechten geen verplichte vakken zijn. ${ }^{47}$

Voor politie ${ }^{48}$ en personeel werkzaam in infrastructuren waar kinderen en jongeren verblijven die van vrijheid zijn beroofd, ${ }^{49}$ gelden bijzondere personeelsvereisten.

Het Jeugddelinquentiedecreet bedt deze kwaliteitsvereiste terecht in als een van zijn grondbeginselen (art. 3, par. $2,1^{\circ}$ ). Verder in het decreet verwijzen verschillende bepalingen naar de rol en opdracht van het Openbaar Ministerie, de jeugdrechter en de advocaat.

Een belangrijke aandacht bij de verdere implementatie van opleiding, bijscholing en specialisatie is dat er naast kennis, bovenal ook wordt ingezet op kunde, met name vaardigheden, ervaring en attitudes. Het is dus niet voldoende dat actoren louter bekend zijn met het jeugddelinquentierecht in al zijn aspecten. Deze actoren moeten vanuit een kinderrechtenperspectief handelen in hun omgang met jongeren die met het jeugddelinquentierecht in aanraking komen.

Het kinderrechtelijk kader stelt eveneens dat de actoren binnen het jeugddelinquentierechtssysteem een weerspiegeling vormen van de diversiteit onder hun cliënten, minstens op het vlak van gender, cultuur, etniciteit en geloof..$^{50}$

Deze gespecialiseerde actoren verdienen, ten slotte, binnen hun beroepsgroep én op decretaal vlak erkenning. Het is dus belangrijk dat zeker van het statuut van jeugdadvocaat verder werk wordt gemaakt. Ook bij de politionele en gerechtelijke actoren, met name Openbaar Ministerie, moet de piste van gespecialiseerde eenheden verder worden uitgebouwd en ondersteund.

\subsubsection{Dataverzameling}

Kinderrechten beschouwen wetenschappelijk onderzoek en wetenschappelijke evaluatie als een noodzakelijke schakel in de verbeteringscyclus bij de aanpak en het aanbod van verscheidene reacties op delictgedrag van jongeren. De evaluatie dient regelmatig plaats te vinden en gebeurt vanuit een breed perspectief. Minstens de volgende invalshoeken komen aan bod: de toepassing, de aard en effectiviteit van de onderscheiden interventies, inzicht in de recente trends, problemen en oorzaken van (jeugd)criminaliteit, discriminatie, herintegratie en reci-

47. Zie ook Defence for Children International Belgium, 'My lawyer, My rights. De rol van de advocaat van de minderjarige in de jeugdbeschermings- en strafrechtelijke procedures in België', september 2016-februari 2017, co-gefinancierd door het Justitie Programma van de Europese Unie, www.dei-belgique.be/IMG/pdf/rapport_mlmr_complet_nl.pdf, 60 e.v.

48. Regel 12.1 Beijing Rules.

49. Deze vereisten slaan op aanwerving en selectie, opleiding en (bij)scholing, samenstelling van de equipe, rechten en plichten en de werkomstandigheden en de organisatie van het werk op zich: regel 22 Beijing Rules; regels 51 en 81-87 Havana Rules; par. 95 en 112 Algemene Commentaar nr. 24 en art. 18, 19.1, 89.3, 90.3, 127.1, 128, 129.1-129.3, 130-134 en 192.2 ERJ. Voor een uitvoerige analyse van toepasselijke internationale regelgeving: Onderzoeksrapport Rechtspositie Jongere in Detentie 2009, 91-100.

50. Regel 22.2 Beijing Rules en art. 128.3 ERJ dive. Bij voorkeur voert een onafhankelijke academische instelling deze evaluatie uit. Ook kinderen en jongeren, in het bijzonder zij die in aanraking zijn gekomen met het jeugd(delinquentie)recht, moeten bij de evaluatie worden betrokken. Het is de opdracht van de overheid om de nodige data te verzamelen. ${ }^{51}$

Binnen het Jeugddelinquentiedecreet wordt evidence based werken als grondbeginsel naar voren geschoven (art. 3, par. 2, $5^{\circ}$ ). In deze optiek dient de Vlaamse Regering dan ook binnen de drie jaar na de inwerkingtreding ervan een evaluatie van dit decreet bij het Vlaams Parlement in te dienen (art. 88). Een nog op te richten interventiedatabank waarin goed onderbouwde en effectieve reacties staan die in de praktijk worden uitgevoerd met betrekking tot jeugddelinquentie, bundelt kennis en inzichten. Het zicht vergroten op het effect van de uitgesproken reactie, is het doel. ${ }^{52}$ Diensten die werken met jongeren die strafbare feiten hebben gepleegd of hiervan verdacht worden, bezorgen in de regel geanonimiseerde persoonsgegevens aan de Vlaamse overheid (art. 43, lid 1). Het uitwisselen van gecodeerde persoonsgegevens is de uitzondering en kan pas na vervulling van bijzondere voorwaarden (art. 43, lid 2 en 3).

Het is zeker een verdienste van Vlaanderen dat het effectief werkt maakt van voldoende, actuele, nauwkeurige en geanonimiseerde respectievelijk gecoördineerde gegevens met betrekking tot kinderen en jongeren die met het jeugddelinquentierechtssysteem in aanraking komen. Het komt zo tegemoet aan een oud zeer, namelijk het gebrek aan een voldoende, actuele, nauwkeurige en gecoördineerde dataverzamelingsbeleid, in het bijzonder van kwetsbare groepen, waarvoor België reeds meerdere malen door onder meer het VN-Comité voor de Rechten van het Kind op de vingers werd getikt. $^{53}$

De focus mag echter niet beperkt blijven tot effectiviteit, efficiëntie en wat werkt. Een dataverzamelingsbeleid moet uitdrukkelijk ook onderzoek toelaten over onder meer de aard, de achtergrond, de omvang en de

51. Regel 30 Beijing Rules; regel 20-21 Tokyo Rules; par. 113-115 Algemene Commentaar nr. 24 en 135-138 ERJ.

52. MvT, 10-11 en art. 43 Jeugddelinquentiedecreet.

53. Punt 8 VN-Comité voor de Rechten van het Kind, Slotbeschouwingen Belgisch landenrapport - Concluding observations on the initial state report of Belgium, 20 juni 1995, UN Doc. CRC/C/15/Add.38, www.kekidatabank.be/index.php?|v|=notice_display\&id=253; punt 4, 14 en 15 VN-Comité voor de Rechten van het Kind, Slotbeschouwingen Belgisch landenrapport - Concluding observations on second state report of Belgium, 13 juni 2002, UN Doc. CRC/C/15/Add.178, www.kekidatabank.be/index.php?|v|=notice_display\&id=254; punt 8, 21-22, 32 en 43 VN-Comité voor de Rechten van het Kind, Slotbeschouwingen Belgisch landenrapport - Concluding observations on the combined third and fourth state reports of Belgium, 18 juni 2010, UN Doc. CRC/C/BEL/CO/3-4, www.kekidatabank.be/index.php? $|v|=$ notice_display\&id=256 en punt 11, VN-Comité voor de Rechten van het Kind, Slotbeschouwingen Belgisch landenrapport - Concluding observations on the combined fifth and sixth state reports of Belgium, 1 februari 2019, onuitgegeven versie, https://tbinternet.ohchr.org/ Treaties/CRC/Shared\%20Documents/BEL/

CRC_C_BEL_CO_5-6_33811_E.pdf. 
evolutie van jeugddelinquentie en de re-integratie van de jongere in de samenleving. Een van de grondbeginselen van het decreet is immers het multidisciplinair inzetten op preventie en de onderliggende oorzaken van jeugddelinquentie aanpakken. Op dit moment wordt het doel hiervan evenwel verengd tot recidivevermijding (art. 3, par. $1,5^{\circ}$ ).

Het blijft een open vraag of na een dergelijke evaluatie wetenschappelijk gefundeerde feiten die huidige keuzes in vraag stellen of de 'onwerkzaamheid' ervan aantonen, gevolgd worden en een decretale inbedding krijgen. Minstens vanuit een kinderrechtenperspectief moet dit nauwgezet opgevolgd worden.

Bij de opmaak van het Jeugddelinquentiedecreet is alleszins duidelijk dat dit voor uithandengeving niet het geval is. Ondanks verscheidene nationale en internationale (longitudinale) wetenschappelijke bevindingen die de contraproductiviteit van uithandengeving vaststelden, de internationale eis (bij monde van het $\mathrm{VN}$ Comité voor de Rechten van het Kind) tot afschaffing van dit systeem, waarbij in Vlaanderen kinderrechtenactoren, academici, een aantal gerechtelijke actoren en andere professionele actoren werkzaam in het jeugddelinquentierechtssysteem aansloten en de uitbreiding van het sanctiepakket in het Jeugddelinquentiedecreet met de mogelijkheid tot een langdurige gesloten begeleiding tot ver na de leeftijd van 18 jaar, bleef het een politieke keuze het systeem van uithandengeving te behouden, het vooropgesteld evidence based-principe ten spijt. ${ }^{54}$

Een participatief jeugddelinquentierecht dat uitgaat van de verantwoordelijkheid van de jongere betrekt bovendien ook de betrokken jongeren zelf bij de evaluatie.

\subsubsection{Verbinding met het nationaal ontmikkelingsproces}

Een jeugddelinquentiesysteem, ten slotte, is onlosmakelijk verbonden met het nationaal respectievelijk regionaal ontwikkelingsproces dat elk land doormaakt, op vlak van jeugdhulpverlening, armoedebestrijding, meer humane justitie enz.

Het Jeugddelinquentiedecreet schrijft het inzetten op preventie en de aanpak van de onderliggende oorzaken van jeugddelinquentie in als een grondbeginsel (art. 3, par. $\left.1,5^{\circ}\right)$. De memorie van toelichting benadrukt hierbij het belang van, en de onlosmakelijke link tussen, de aanpak van jeugddelinquentie en een breder beleid met betrekking tot minderjarigen. Acties en initiatieven van preventieve aard worden hierin gekaderd. ${ }^{55}$

De context of omgeving waarin de minderjarige leeft, wordt mee onderzocht respectievelijk in overweging genomen bij het voorstellen of opleggen van een reactie. Dit is geformuleerd als een grondbeginsel (art. 3, par. 2, $4^{\circ}$ ). Sociale onderzoeksopdrachten (art. 7), rekening

54. Voor een kritische analyse: S. Pleysier, 'Vlaanderen bouwt aan een jeugddelinquentierecht. Uithandengeving blijft anomalie', 6 februari 2018, https://sociaal.net/achtergrond/vlaanderen-bouwt-jeugddelin quentierecht/.

55. MvT, 5. houden met de leefomgeving van de jongere als motiveringsvereiste alvorens een sanctie op te leggen (art. 16, par. $1,5^{\circ}$ ) en maatschappelijke en medisch-psychologische onderzoeken (art. 38, par. 3) geven meer concrete inhoud.

Aangezien er nog steeds linken blijven bestaan tussen de aanpak van jeugddelinquentie en jeugdhulpverlening (cf. 'combineerbare sporen') kan de decretale aandacht voor de rechtswaarborgen van jongeren, en in het bijzonder hun rol en positie van de jongere, een belangrijke katalysator zijn. Een van de randvoorwaarden om verantwoordelijkheden op te nemen is dat kinderen en jongeren weten in welke procedure ze zitten en waarom, waar ze aan toe zijn, wat er van hen verwacht wordt (kan worden) en welke invloed ze zelf kunnen en mogen hebben. Transparantie, duidelijkheid en consistentie zal dan ook een blijvend aandachtspunt blijven bij de toepassing en de uitrol van het decreet.

De verantwoordelijkheid van de jongere als uitgangspunt nemen, waarbij ook rekening wordt gehouden met zijn context, kan maar pas vorm aannemen en een antwoord bieden op de aanpak van jeugddelinquentie als dit de individuele benadering overstijgt en expliciet(er) geplaatst wordt binnen de nationale (regionale) ontwikkelingen. Dit impliceert dat niet enkel de ouders en opvoedingsverantwoordelijken de context van een jongere vormen, een rol te vervullen hebben en op hun verantwoordelijkheden aangesproken kunnen worden. Een jeugddelinquentierechtssysteem is geen geïsoleerd eiland binnen de samenleving. De context van de jongere wordt evenzeer gevormd door de socio-economische levensstandaard, de gezondheidszorg, het onderwijs, de vrije tijd, de buurt ... Ook daarvoor moet een volwaardig jeugddelinquentierechtssysteem aandacht hebben. Elk van deze contexten draagt eveneens een verantwoordelijkheid en dient mee in rekenschap te worden gebracht voor het welslagen van de aanpak van en reageren op jeugddelinquentie. Hierbij spelen preventieve acties en maatregelen, die de loutere focus op jeugddelinquentie overstijgen, een verbindende rol.

\section{Het Jeugddelinquentie- decreet getoetst aan de vereisten van het $\mathrm{VN}$ - Comité voor de Rechten van het Kind}

De opmaak van het Jeugddelinquentiedecreet spoorde met de verplichte rapportage aan het $\mathrm{VN}-$ Comité voor de Rechten van het kind over de implemantie van het Kinderrechtenverdrag. ${ }^{56}$ Het proces en de inhoud van

56. Een overzicht van het proces met alle documenten is te vinden op de site van de Nationale Commissie voor de Rechten van het Kind: https:// 
het toen nog ontwerp van decreet kwam aan bod in de officiële verslaggeving als in de alternatieve rapporten, in het tussentijds rapport waarin het comité aan België bijkomende vragen stelde (de zgn. list of issues) en in de uiteindelijke Slotbeschouwingen van 1 februari 2019.

Hoewel het Comité de opvolging van knelpunten opgenomen in de Slotbeschouwingen van 2010 verwelkomt, uit het zijn ernstige bezorgdheid. Aan - vele - andere aanbevelingen werd nog steeds geen gevolg gegeven. Het Comité dringt dus aan hiervan werk te maken tegen het volgende raportagemoment. België, en bij uitbreiding Vlaanderen, wordt aangespoord om: ${ }^{57}$

- elke mogelijkheid voor een kind om voor een gemone rechtbank te morden berecht en samen met volmassenen in hechtenis te worden genomen, af te schaffen;

Vlaanderen doet dit niet, maar zet het Belgische beleid van uithandengeving, mits enkele aanpassingen, gewoon verder.

Het blijft betreurenswaardig dat Vlaanderen niet heeft gekozen om binnen één systeem een volwaardig antwoord op een verscheidenheid van situaties regelgevend uit te werken. Door te kiezen voor dubbele leeftijdsgrenzen, werd geopteerd voor het behoud van een diffuus systeem dat bovendien systematisch door het VNComité voor de Rechten van het Kind wordt veroordeeld. Het Jeugddelinquentiedecreet was de uitgelezen kans om de uithandengeving af te schaffen, en resoluut te kiezen voor een jeugdrecht voor álle kinderen en jongeren. Vlaanderen heeft hierdoor zijn ambitie om zich 'internationaal als goede praktijk in de aanpak van jeugddelinquentie te profileren' duidelijk bijgeschroefd en getemperd. Ook zijn pleidooi voor een evidence-based jeugddelinquentierecht met de expliciete afstemming van reacties op delicten op 'vernieuwde (jeugd)criminologische inzichten', is hiermee te nuanceren.

- ervoor te zorgen dat er onvermijld toegankelijke en gekmalificeerde rechtsbijstand mordt verleend;

Het Jeugddelinquentiedecreet voorziet hierin en geeft zo, op theoretisch vlak althans, een afdoend antwoord.

- buitengerechtelijke maatregelen, zoals diversie, bemiddeling en advisering, voor kinderen die verdacht worden van het plegen van strafbare feiten en, waar mogelijk, het uitspreken van niet-vrijheidsberovende sancties, zoals probatie of gemeenschapsdienst, te bevorderen;

Vlaanderen zet in op een aanbod van buitengerechtelijke en gerechtelijke afhandelingen. Er kunnen wel kanttekeningen worden geplaatst door buitengerechtelijke afhandeling (diversie) uitsluitend in te vullen vanuit een rol-

ncrk-cnde.be/nl/periodieke-verslaggeving-belgie-aan-het-vnkinderrechtencomite/vijfde-en-zesde-periodiek-verslag-2017/.

57. Punt 46, VN-Comité voor de Rechten van het Kind, Slotbeschouwingen Belgisch landenrapport - Concluding observations on the combined fifth and sixth reports of Belgium, CRC/C/BEL/CO/5-6, 1 februari 2019, https://tbinternet.ohchr.org/Treaties/CRC/Shared \%20Documents/BEL/CRC_C_BEL_CO_5-6_33811_E.pdf. Een overzicht van de eerdere opmerkingen van het VN-Comité voor de Rechten van het Kind is terug te vinden in het Rapport Kinderrechtelijk kader Omgevingsanalyse Jeugdrecht 2015, 32-33. bedeling aan het Openbaar Ministerie. Het aanbod van maatregelen die het Openbaar Ministerie kan voorstellen, is aangevuld met voorwaarden en het positief project.

Op niveau van de gerechtelijke afhandeling werd ingezet op het aanbod van niet-vrijheidsberovende sancties. Voor het welslagen van deze veelheid aan reactiemogelijkheden, zodat deze geen dode letter zouden blijven, noch verstrikt geraken in wachtlijsten en dergelijke, is een investering - niet louter te verengen tot financiële impulsen - een absolute vereiste.

De buitengerechtelijke afhandeling beantwoordt maar gedeeltelijk aan de gestelde minimumvereisten van rechtswaarborgen en heeft slechts oog voor één actor die de regie in handen heeft: het Openbaar Ministerie. Het is een gemiste kans dat de betekenis van 'buitengerechtelijk' in zijn puurste vorm, als buiten ieder contact met justitiële actor om, niet werd bekeken.

- gesloten opvang als laatste redmiddel en voor de kortst mogelijke termijn te gebruiken; in gevallen maarin gesloten opvang onvermijdelijk is, ervoor te zorgen dat de opsluitingsvoormaarden in overeenstemming zijn met de internationale normen, onder meer wat betreft de toegang tot ondermijs en gezondheidszorg en dat kinderen die van hun vrijheid zijn beroofd, worden vastgehouden in faciliteiten in de nabijheid van hun verblijfplaats en bereikbaar via openbaar vervoer, en dat de gesloten opvang regelmatig mordt herzien met het oog op de intrekking ervan;

Vrijheidsberoving wordt in het Jeugddelinquentiedecreet ingeschreven als uiterste reactie, als maategel (art. 20, par. 2) zowel als sanctie (art. 29, par. 2-3). De uitvoering van de vrijheidsberovende maatregelen en sancties moeten zo dicht mogelijk bij de verblijfplaats van de minderjarige of zijn ouders/opvoedingsverantwoordelijken worden uitgevoerd (art. 17). Ook aan de vereiste van regelmatige herziening van mogelijkheid van gesloten plaatsing met oog op intrekking komt Vlaanderen tegemoet (art. 16).

Binnen de gerechtelijke afhandelingen wordt ingezet op een breed aanbod van niet-vrijheidsberovende, vrijheidsbeperkende en ten slotte vrijheidsberovende reacties als ultimum remedium. Dat is positief. Nochtans blijft er een bezorgdheid dat de doelen van re-integratie, herstel, inzicht en verantwoordelijkheid worden weggedrukt door repressie, individuele aansprakelijkheid en een nadruk op beveiliging van de maatschappij. Zo werd de duurtijd van maatregelen en sancties verzmaard of verhoogd zonder enige afdoende motivering of verantwoording. Een investering in effectieve implementatie, inwerkingtreding en groeimogelijkheid van niet-vrijheidsberovende maatregelen is bovendien absoluut nodig wil men ervoor zorgen dat (de toevlucht tot) het opleggen van vrijheidsberovende maatregelen vermindert zodat deze effectief een uiterste maatregel worden.

De uitgebreide mogelijkheden van vrijheidsberoving, het naast elkaar laten bestaan van de uithandengeving en gesloten begeleiding voor ten hoogste zeven jaar, de vaak vage en voor interpretatie vatbare criteria voor vrij- 
heidsberoving (omstandigheden, voorwaarde, finaliteit ...), de uitgebreide aandacht binnen het decreet zelf en in de memorie van toelichting aan vrijheidsberoving met regelmatig een link aan de eis van beveiliging van de maatschappij, wekt echter niet de indruk dat vrijheidsberoving echt het ultimum remedium is. In het bijzonder de gesloten begeleiding voor maximum zeven jaar gekoppeld aan een terbeschikkingstelling na de afloop ervan verdient bijzondere aandacht en opvolging. Deze reactie is niet te beschouwen als een 'koude detentie' en moet leiden tot herintegratie en heropvoeding. Zeker bij deze vorm van sanctioneren staan een aantal kinderrechten onder druk, waaronder recht op contact (art. 10, lid 2 Kinderrechtenverdrag), recht op gezondheidszorg (art. 24 Kinderrechtenverdrag), recht op periodieke herziening (art. 25 Kinderrechtenverdrag), recht op onderwijs (art. 28 en 29 Kinderrechtenverdrag) en recht op vrije tijd, ontspanning en culturele activiteiten (art. 31 Kinderrechtenverdrag). Verantwoordelijkheid (leren) opnemen, inzichtverwerving, herstel en mogelijkheden en kansen tot herintegratie in de samenleving zijn maar mogelijk als naast de aandacht voor de aanpak van jeugddelinquentie, minstens evenwaardige invulling wordt gegeven aan kinderrechten die bijdragen tot burgerschap en menselijke waardigheid.

De toegang tot kwaliteitsvol en gevalideerd onderwijs voor geplaatste jongeren blijft voor Vlaanderen een belangrijke uitdaging waarvan dringend werk moet worden gemaakt.

Vrijheidsberoving als ultimum remedium vraagt een mentaliteitswijziging. De Vlaamse overheid draagt hier dus een zeer grote verantwoordelijkheid om haar beleid en principes in daden om te zetten. Ze zal 'het goede voorbeeld moeten geven'. Immers: de vraag naar meer detentiecapaciteit, met inbegrip van gesloten plaatsing, klinkt in Vlaanderen steeds luider. ${ }^{58}$ Niet onmiddellijk opsluiten van jongeren (ook tijdens de onderzoeksfase) leidt vaak tot onbegrip in de pers, bij de burger, als in politieke kringen. Ingaan op vragen van capaciteitsuitbreiding, onbegrip - dat vaak slechts gestoeld is op meningen - niet weerleggen met feiten enz. staan haaks op het principe van vrijheidsberoving als laatste reactie.

Dit beginsel is nochtans een fundamenteel mensenrecht én kinderrecht. Het is absoluut niet te beschouwen als een intentie of een voornemen.

- ervoor te zorgen dat advocaten en rechters porden opgeleid op vlak van kinderrechten en kindvriendelijke benaderingen;

De Orde van Vlaamse balies organiseert in samenwerking met de universiteiten en hogescholen opleidingen jeugdrecht voor (jeugd)advocaten). Ook de magistratuur en gerechtelijke stagiairs krijgen vormingen, georganiseerd vanuit de Hoge Raad voor Justitie. Het is raad- zaam om deze opleidingen vanuit een kinderrechtenperspectief regelmatig door te lichten en aan te vullen en te verfijnen waar nodig en gepast. Aanvullend op kennisoverdracht moeten deze opleidingen evenzeer inzetten op kunde, vaardigheden en attitudes.

\section{Besluit}

België, met inbegrip van Vlaanderen, maakt al jarenlang werk van een graduele vertaling van kinderrechten op het vlak van het omgaan met jeugddelinquentie naar regelgeving, beleid en praktijk. Een Vlaams jeugddelinquentiedecreet moet zowel bij de opmaak als de uitvoering ervan het kinderrechtenkader respecteren, implementeren en naleven, wil het kinderrechtenproof zijn.

Tijdens het opmaakproces van dit decreet ging naast vele andere aandachtspunten en na te leven vereisten ook aandacht uit naar de juridische en maatschappelijke betekenis van kinderrechten. Voornamelijk de vraag naar wetenschappelijke onderbouw en de besprekingsfase met experten en direct betrokkenen, waaronder jongeren zelf, onderscheiden zich hierin. Aanvullend op de invulling van kinderrechten als juridische norm, werd op onderscheiden wijzen inzichten gezocht en geboden over de manier waarop er wordt omgegaan met jongeren die strafbare feiten plegen (of hiervan verdacht worden), de implicaties daarvan op verschillende levensdomeinen, de achtergronden en mogelijke antwoorden. Binnen het politieke proces was er voornamelijk oog voor de juridische betekenis van kinderrechten.

Het Jeugddelinquentiedecreet komt in grote mate aan de internationaal gestelde principes tegemoet, al zijn er - zoals hiervoor uiteengezet - wel aan aantal fundamentele kanttekeningen en bezorgdheden.

Het Jeugddelinquentiedecreet kent bijgevolg een (gedeeltelijke) regelgevende inbedding van kinder- en mensenrechten. Dit is een eerste, hetzij onvolledige, stap. De evaluatie en monitoring van de toepassing van het decreet in de praktijk vormt een belangrijke graadmeter om vast te stellen of de juridische én maatschappelijke betekenis van kinderrechten in Vlaanderen worden geëerbiedigd, nageleefd en waar nodig uiteindelijk bijgesteld, met respect voor de voorgenomen internationale en evidence-based ambities. 


\section{'A Young Offender'}

'He was only eighteen, with the baby face of a teenager, when he appeared charged with twelve counts of armed robbery.

During the bail hearing he stared through me A though

Were glass.

Not once did his eyes

Betray the blue fury

Inside him, even when

I refused bail.

Yes, he would go away for awhile

But I knew he'd be back,

Older and deadlier

And I was scared... ${ }^{59}$ 